\title{
The Increasing of Soybeans Production on Dry Land Using Intercropping System
}

\author{
Jamidi $^{1}$, Abdul Rauf ${ }^{2}$,Chairani Hanum ${ }^{2}$ and Erwin Nyak Akop ${ }^{3}$ \\ \{jamidinurdin@yahoo.co.id\} \\ ${ }^{1}$ Doctoral Program of Agriculture Sciences, Faculty of Agriculture, Universitas Sumatera Utara, \\ Padang Bulan, Medan, 20155, Indonesia \\ ${ }^{2}$ Department of Agrotechnology, Faculty of Agriculture, Universitas Sumatera Utara, Padang Bulan, \\ Medan, 20155, Indonesia \\ ${ }^{3}$ Staf Pusat Penilitian Kelapa Sawit, Medan, 20155, Indonesia
}

\begin{abstract}
Soybean production in Indonesia is still low, meanwhile the demand of soybeans keeps increasing every year. The utilization of dry land based on intercropping system is one of solutions to achieve the production target. The research employedfield experiment with Group Randomized Design (hereafter RAK shorten from RancanganAcakKelompok) of non-factorial by conducting cropping pattern I(soybeans, corns, and red chillies were planted in one plot), cropping patternII (soybeans were planted in two rows in one plot; corns were planted in two rows in one plot, and red chillies were planted in two rows in one plot). Cropping pattern III (soybeans were planted, and next to the soybeans, corns and red chillies were planted in three rows in one plot). The research was conducted based on the observation on the number of pods per plant, the number of piths of pods per plant, and the weight of 100 seeds. The result of research shows that on the average number of podsper plant, piths of pods per plant, and the weight of 100 seeds, the development tends to be linear.
\end{abstract}

Keywords: Soybeans, dry land, intercropping

\section{Introduction}

The need of soybean keeps increasing meanwhile the productivity of soybeans is still low due to the factor of high import every year. The situation is worsening by the shrinkle of agriculture land because of land competition between soybeans and other palawija crops (other crops besides rice that is usually planted in a rice field, such as nut, corns, and so forth). The situation happens since Indonesian country does not have specific land to plant soybeanslike ricefield have to plant paddy. One of the solutions to develop soybeans is by utilizing dry land using intercropping system.

Dry land is one of agroecosystems which has big potency for agriculture businesses; one of those is palawija crops. However, dry land has low fertility level, particularly the erosion lands thus layers of soil becomes thin and is low of organic substances [1]. By intercropping system, it is expected that symbiosis happens among plants in order to increase soil fertility.

In this research, intercropping system was using corns and red chillies. The aim of cropping pattern arrangement based on intercropping system is to enable the land surface to be covered in order to reduce evaporation. Corns have large land cover because the morphology 
of bigger plants is expected to reduce evaporation so that the water needs for soybeans can be fulfilled.

Water shortage happens because of limit amount of water from its environment [2]. The plant with lack of water supply on root area and the excessive water requirement by leaves will cause evaporationacceleration [3]. Plants have different responses regarding to water shortage based on physiological, morphological aspects, growing levels, and productivity. Water deficiency suffered by plants will influence their growth and cell development, synthesis of protein, and synthesis of cell wall [4].

Developed Soybean varietal in this research was kipas putihwhich is local varietal from Aceh that has potency to be local excellent varietal because it has adapted and is appropriate to land condition in Aceh. Kipas Putihis resistance from falling down, rust leaf tolerance, and adapts well on dry land and rain-fed rice-field therefore it is very appropriate to be developed on dry land.

The result of research reveals that soybeans planted with intercropping of cornsare able to increase their production 50\% higher if compared with monoculture system. Soybean planting as intercropping on corn crop is also able to improve the land fertility because there is fixation of $\mathrm{N}$ if compared with monoculturesystem of corns (Research and Development Body of Agriculture, 2015). It is expected that this research becomes a cultivation technology which enables to increase soybean production in the future.

\section{Methods}

The implementation of field research employed Group Randomized Design (hereafter RAK shorten from Random Design Group) of non-factorial. The treatment of cropping pattern I was that soy beans, corns, and red chillies were planted together in one plot, which size of plot was $9 \mathrm{~m} \mathrm{x} 4 \mathrm{~m}$. The distance planting of corn was $100 \mathrm{~cm} \times 30 \mathrm{~cm}$; the distance planting of soybeans was $50 \mathrm{~cm} \times 30 \mathrm{~cm}$; the distance planting of red chillies was $100 \mathrm{~cm} \times 50$ $\mathrm{cm}$. The treatment of cropping patternIIwasthatsoybeans were planted in one plot with two rows; The distance planting was $100 \mathrm{~cm}$ x $30 \mathrm{~cm}$; corns were planted in one plot with two rows, the distance planting was $50 \mathrm{~cm} \times 30 \mathrm{~cm}$; red chillies were planted in one plot with two rows, the distance planting was $100 \mathrm{~cm} \times 50 \mathrm{~cm}$. The third treatment wascropping patternIII, which soybeans were planted in three rows with planting distance was $100 \mathrm{~cm}$ x $30 \mathrm{~cm}$, corns were planted next to the soybeans in three rows which planting distance was $50 \mathrm{~cm} \times 30$ $\mathrm{cm}$, and red chillies with three rows with planting distance was $100 \mathrm{~cm} \times 50 \mathrm{~cm}$. Control treatment wasasthe comparison which three commodities were planted in monoculture way: planting distance of corns was $100 \times 30 \mathrm{~cm}$; planting distance of soybeans was $50 \mathrm{~cm} \times 30 \mathrm{~cm}$ andplanting distance of red chillies was $100 \mathrm{~cm}$ x $50 \mathrm{~cm}$, with size of plot was $9 \mathrm{~m} \times 4 \mathrm{~m}$. Each cropping pattern had three arrangement combinations of treatments with three repetitions with total of 27 units of experiment plots for one cropping pattern plot. The size of plots was $900 \mathrm{~cm} \times 400 \mathrm{~cm}$, the distance among plots was $50 \mathrm{~cm}$; in cropping pattern I, planting distance was $100 \mathrm{~cm} \times 30 \mathrm{~cm}$; the planting distance of soybeans was $100 \mathrm{~cm}$ x $30 \mathrm{~cm}$, and the planting distance of red chillies was $100 \mathrm{~cm}$ x $50 \mathrm{~cm}$. In cropping pattern II and III, planting distances of corns were $100 \mathrm{~cm}$ x $30 \mathrm{~cm}$; planting distance of soybeans was $50 \mathrm{~cm}$ x $30 \mathrm{~cm}$, and planting distance of red chillies was $100 \mathrm{~cm}$ x $50 \mathrm{~cm}$. The arrangement of planting distance of intercropping of corns with soybeans and red chillieswas on cropping pattern system. Whole experiment units were repeated three times. 


\section{Research Implementation}

The cultivated land for planting should be cleaned up first from grass and other dirt,and then the soil was treated using tractor and was flattened. Furthermore, the plots were made with size of each plot was $9 \mathrm{~m} \mathrm{x} 4 \mathrm{~m}$, the distance among beds was $50 \mathrm{~cm}$ and the distance among blockswas $50 \mathrm{~cm}$. The soybean seed planting with distance of $50 \mathrm{~cm} \times 30 \mathrm{~cm}$, corns were done by dibble sticks with distance $100 \mathrm{~cm} \mathrm{x} 30 \mathrm{~cm}$, and each hole was planted with two seeds of corns, red chillies were planted with distance $100 \mathrm{~cm} \times 50 \mathrm{~cm}$. The spacing was done in order to allow the optimal growing condition of soybean, corn, and red chilli plants.

The maintenance of soybeans, corns, and red chillies consisted of weed control, sticthing, and pests and deseases control. The watering was done twice a day in morning and afternoon in order to prevent the plants from water deficiency however watering was not done during rainy days. The stitching aimed to change the plants which were growing in abnormal way or regarding to dead seeds, the stiching was done for one week after planting period. The pest and disease control were done if corns, red chillies, and soybeans were affected by pests and diseases. The harvest of soybeans was done at the age 85-90 days after planting time, the ripen plants with physiologic form characterized by $95 \%$ of pods was already in brown colour, the leaves turned to dry and fall, as well as the age of plants was adequate to be harvested.

\section{Result and Discussion}

\subsection{The Number of Pods Per Year}

The average calculation of the number of pods persoybean planting using dry land optimally based on intercropping treatment of corns and red chillies indicates that the development tends to be linear (figure 36).

Figure 36 shows that those samples 3,5 on planting 1 (one) rowhas increasing number of pods per soybean planting as the rows of corns and red chillies increase. Meanwhile, on samples of rows $1,6,12$, the increasing number of pods per plants is up to 2 (dua) rows of intercropping of corns and red chillies, however the increasing of 3 (three) rows of intercropping does not contribute the effect on the increasing number of pods per soybean plant.

The different responses of number of pods per plant are because thoseare influenced by variety of development vegetative periods of varietal and environmental condition. This research usedkipas putih varietal which has the stem growth of semi-determinate.The development of stem keeps continuing well although the plants have flowered. Thus it affects on the competition to result photosynthesis, and the potency of miscarriage of flower is bigger. The percentage of success of flowers to form pods determines the number of pods per plant.

Intercropping system influences the environmental condition of soybean growth which is the length of days and the temperature. It was found on planting 2(two) rows of soybeans which caused the increasing number of pods per plant on samples 8,10 with the increasing rows of corns and red chillies. Meanwhile on samples 2, 12, it shows that there is no increasing number of pods per soybean plant with the increasing rows of corns and red chillies as intercropping plants. 
The increasing number of rows of corns as intercropping reduces the reception of sunlight by soybeans. The morphology of taller corns causes changes the length of the day and temperature in soybean rows. The length of the day in soybeans' rows exceeded the critical limit which causes the decreasing number of pods per plant of soybeans with the increasing number of rows of corns and red chillies.

It is shown that on samples, 4, 6, 10 on the planting of 3 (three) rows, the increasing number of pods per plant of soybeans is up to 2 (two) rows of intercropping of corns and red chillies. The increasing number of intercropping becomes3 (three) rows of corns and red chillies does not cause the increasing number of pods per plant.

Soybean varietal will flower if the dark period received daily is less than 10 hours. On the other hand, the soybean plants will flower fast if the dark period is between 14-16 hours per day(Adie \& Krisnawati, 2008). The effect on changeof length of the day and temperature in rows of soybeans is that the percentage of flower becoming pods is not optimal.

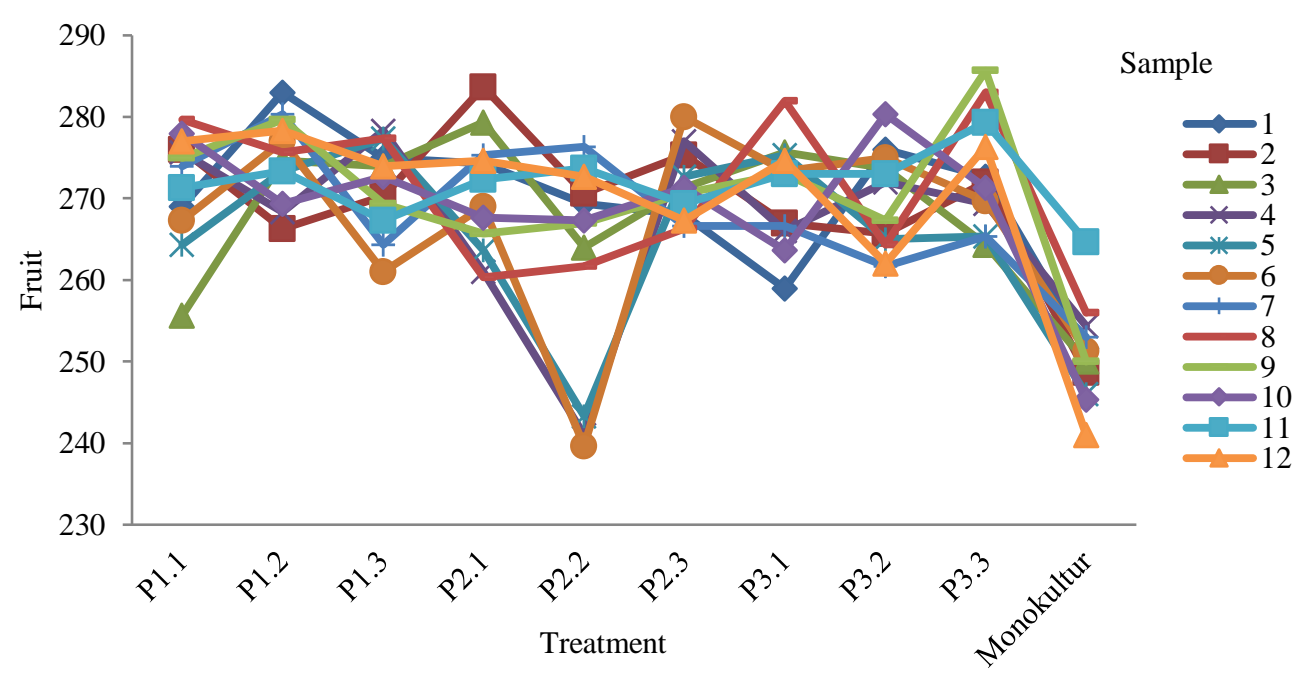

Graphic Information:

From sample1 to 12 for cropping patterns I, II and III of all repetitions.

$$
\begin{gathered}
y=-1,64 x+278,8 \\
R^{2}=0,309 \\
y=-1,666 x+278,7 \\
R^{2}=0,305 \\
y=-0,780 x+272,5 \\
R^{2}=0,061
\end{gathered}
$$

$$
\begin{aligned}
& \qquad \begin{array}{c}
y=-1,323 x+271,9 \\
R^{2}=0,118
\end{array} \\
& \quad \begin{array}{l}
y=-0,436 x+268,7 \\
R^{2}=0,011
\end{array} \\
& y=-2,078 x+279,8 \\
& R^{2}=0,595
\end{aligned}
$$

C $\quad \mathrm{y}=-1,014 \mathrm{x}+275,9$

$\mathrm{R}^{2}=0,105$

$$
\begin{aligned}
& 1 \quad \begin{array}{r}
y \\
0 \quad \\
R^{2}=0,228
\end{array} \\
& 1 \quad y=0,049 x+271,4
\end{aligned}
$$$$
1 \quad R^{2}=0,001
$$ 


$$
\begin{aligned}
& \mathrm{y}=-1,004 \mathrm{x}+271,8 \\
& \mathrm{R}^{2}=0,069
\end{aligned}
$$
: $\quad \mathrm{y}=-0,951 \mathrm{x}+275,8$ $\mathrm{R}^{2}=0,083$
$1 \quad y=-2,444 x+283,2$
$2 \quad \mathrm{R}^{2}=0,433$

Figure 36. The average number of pods per soybean plant on intercropping pattern of corns and red chillies.

\subsection{Total Piths of Pods Per Plant}

The average calculation of total piths of pods per soybean plant on the optimally used dry land based on intercropping treatment of corns and red chillies shows that the development tends to be linear (figure 37).

Figure 37 shows that the samples 11, 12on planting 1 (one) rowshave increasing number of piths of pods per soybean plant as the number of rows of corns and red chillies as intercropping increases. The number of pods varies in one of flowering, and one pod in general contains from 1-3 seeds per pod. It is caused by the research site on dry land which has chemical fertility and low rainfall. However the average number of piths of pods per plant is higher than monoculture system as the control.

Pod filling is the critical period for soybeans in achieving the number piths of pods per plant optimally. The fresh weight and the maximum size of seed will be attained from 5-15 days after flowering [5]. The water shortage happens because dry land is identic with low groundwater content and the air temperature is high. The research location which is hilly and windy speed is high causing low rainfall. The increasing number of rows of intercropping of corns and red chillies causes the creasing competition among sample plants. It can be seen on samples $8,9,10$ that the number of piths of pods increases per plant just 2 (two) rows of corns and red chillies. The increasing of 3 (three) rows does not cause the increasing number of piths of pods per plant.

The increasing number of soybeans into 2 (two) rows has caused the increasing number of piths of pods with the increasing rows of corns and red chillies as intercropping which only happens on sample 10 . On the other hand, the samples $3,4,5,6$, which cause the increasing number of piths of pods only on 2 (two) rows ofcorns and red chillies and the raising number of rows became 3 (three) rows of corns and red chillies do not cause the increasing number of pith of pods per plant.

The planting 3 (three) rows of soybeans causes the increasing number of piths of pods per plant on samples 7, 9, 10. However on the other samples, the increasing number of piths of pods per soybean plant does not occur as the number of rows of corns and red chillies increases. The raising population by increasing number of rows of soybeans cause the competition on the water demand, nutrient, and sunlight higher. It is assumed that the factor that affects the decreasing number of piths of pods because dry land has low chemical fertility and low groundwater content.

The research was conducted on dry land with hilly topography and thin layer organic substance. The soil layer becomes thin and the level of organic substance is low because the land is eroded [6]. Organic substance has crucial role in improving chemical character, physic, and soil biology. Although the contribution of soil organic matter as substance resource is relatively low, its role is prominent as the source of NPK and other essential resources such as $\mathrm{C}, \mathrm{Zn}, \mathrm{Cu}, \mathrm{Mo}, \mathrm{Ca}, \mathrm{Mg}$, and $\mathrm{Si}[7]$. 
The pest-sucking attack on pods during filling phase became main factor that many samples were not able to increase the number of piths of pods per plant. The research on the field was difficult to accommodate the land free of pest and disease however the preventive action using pesticide had been done even the result was not maximal in controlling the pestsucking attack on the pods.

The loss of production due to the pest-sucking attack reaches up to $79 \%$ [8]. The attack happens during pod formation and after pod formation completely. It causes the shrink of seeds, deflated seed, and pod miscarriage [9]. The other effect is the black spits on the seeds that cause the quality of the seeds decreases [10].

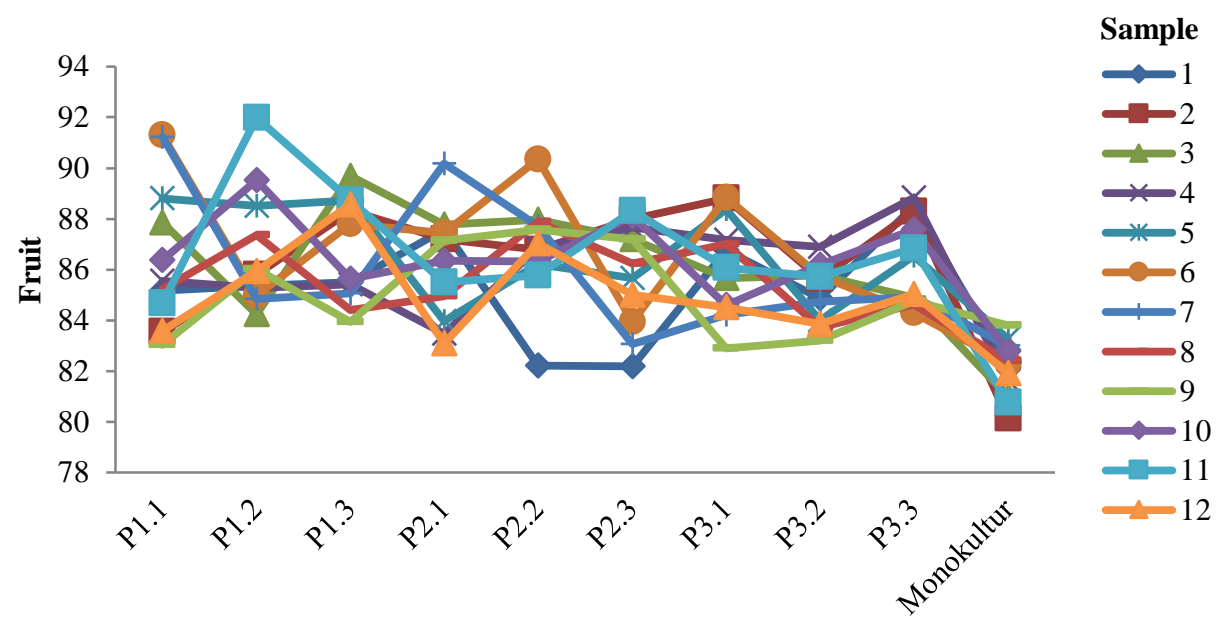

\section{Treatment}

Graphic information:

From samples 1 to samples 12 for cropping patterns of I, II and III of all repetition

$$
\begin{aligned}
& y=-0,066 x+85,38 \\
& R^{2}=0,007 \\
& y=-0,126 x+86,94 \\
& R^{2}=0,020 \\
& y=-0,508 x+88,99 \\
& R^{2}=0,391 \\
& y=0,051 x+85,59 \\
& R^{2}=0,005
\end{aligned}
$$

$$
\begin{aligned}
& y=-0,452 x+88,89 \\
& R^{2}=0,405 \\
& y=-0,595 x+89,97 \\
& R^{2}=0,378 \\
& y=-0,591 x+89,14 \\
& R^{2}=0,393 \\
& y=-0,262 x+86,82 \\
& R^{2}=0,212
\end{aligned}
$$

C. $y=-0,112 x+85,57$ $\mathrm{R}^{2}=0,033$

$$
\begin{array}{ccr} 
& 1 & y=-0,281 x+87,88 \\
0 & R^{2}=0,211 \\
& & y=-0,497 x+89,17 \\
& 1 & y=0,265 \\
1 & R^{2}=0 \\
& & y=-0,259 x+86,27 \\
& 1 & R^{2}=0,161
\end{array}
$$

Figure 37. The average calculation of number of pith of pods of soybeans on intercropping patterns of corns and red chillies. 


\subsection{Weight of 100 Seeds}

The average calculation of weight of 100 seeds of soybeans on the optimized dry land utilization based on intercropping treatment of corns and red chillies shows that the development tends to be linear (Figure38).

Figure 38 shows sample 1 on planting 1 (one) row that weight of 100 seeds of soybeans increases as the number of rows of corns and red chillies increases. However the increasing is not significant which it is assumed that the strategic location of samples, and attains the input production maximally during the growth period so that the weight of 100 seeds is higher than other samples.

Furthermore, on samples 6, 11 weight of 100 seeds increases up to 2 (two) rows of corns and red chillies. The increasing of 3 (three) rows of corns and red chillies as intercropping does not cause the increasing of weight of 100 seeds of soybeans. It happened on samples 4,8 , 10 with the absence of weight of 100 seeds of soybeans which were planted based on intercropping of corns and red chillies.

The planting of intercropping in 1 (one) row of soybeans with some rows of corns and soybeans does not enable to increase the weight of 100 seeds in significant way. However the average weight of 100 seeds based on intercropping system is higher than monoculture system as the control. It indicates that the symbiosisin intercropping system of corns and red chillies is needed to investigate further.

The increasing rows of soybeans that become 2 (two) rows causes the increasing of weight of 100 seeds only on sample 3, 8. In contrary, samples 6, 710 , has increasing only 2 (two)rowsofcorns and red chillies but the increasing of 3 (three) rows of corns and red chillies does not cause the increasing weight of 100 seeds of soybeans. In fact, at the sample 12, it does not cause the increasing weight of 100 seeds of soybeans with the increasing rows of corns and red chillies as intercropping plants.

By the increasing of soybeans in 2 (two)rows, the population becomeshigher.Meanwhile the filling and ripen periods are critical phases to gain weight of 100 seeds optimally. The water demand, nutrient, and sunlight are required at the same time but dry land is only able to provide the limited water supply. It causes the increasing number of rows of soybeans and intercropping plants thus the weight of 100 seeds does not increase.

The planting of 3 (three) rows which can be seen at sample 11 on the planting of 3 (three) rows causesthe increasing weight of 100 seeds of soybeans as the rows of corns and red chillies increase. On the other hand, on the samples 4, 5, 6, 12, the increasing weight of 100 seeds just happens on 2 (two) rows of corns and red chillies. The increasing of 3 (three)rowscorns and red chillies as intercropping plantsdoes not increase the weight of 100 seeds of soybeans.

Most of the seeds are composed of cotyledon and are coated by testa (peel seed) and in between them, there is endosperm layer [11]. Cotyledon is endosperm that is resulted from the process of fertilization between male gametes and the core of embryo [12]. Endosperm cells are the cells which contain large amount of carbohydrate and fat as the result of photosynthesis process [12]. The weight of 100 seeds relies heavily from the amount of those carbohydrate and fat. 


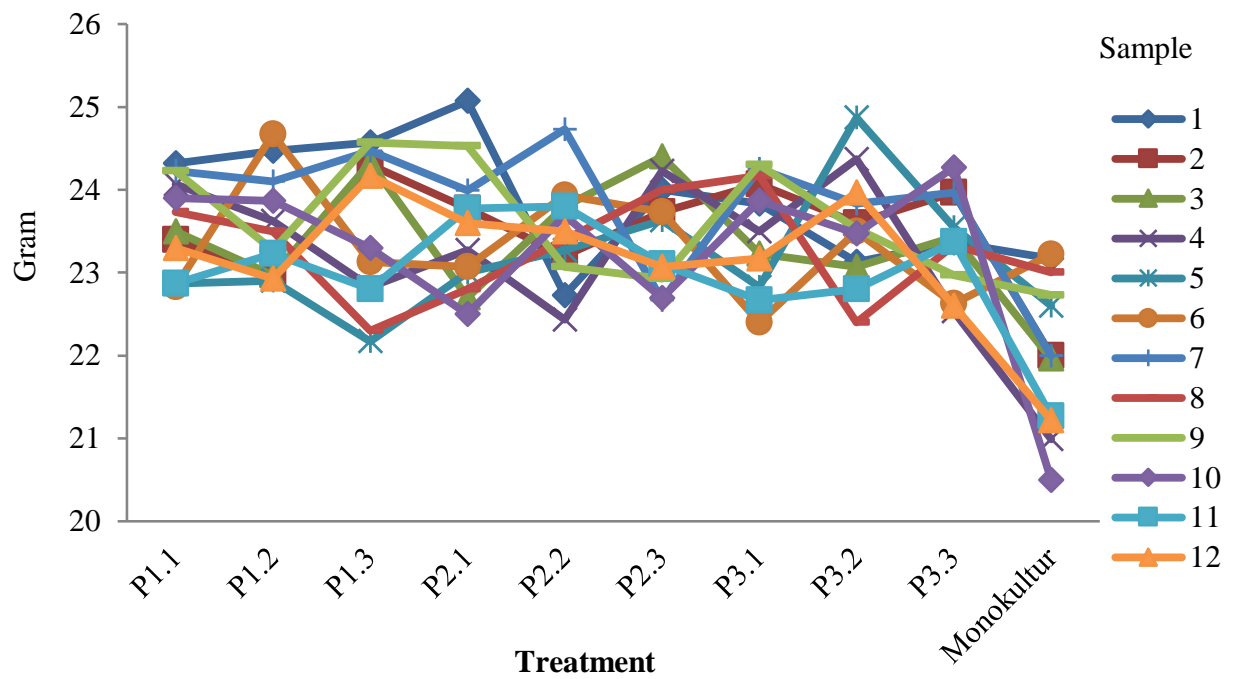

Graphic Information :

From samples 1 to samples 12 for cropping patterns of I, II and III of all repetition

$$
\begin{gathered}
y=-0,168 x+24,79 \\
R^{2}=0,457 \\
y=-0,046 x+23,75 \\
R^{2}=0,045 \\
y=-0,089 x+23,83 \\
R^{2}=0,135 \\
y=-0,152 x+24,02 \\
R^{2}=0,201
\end{gathered}
$$

$$
\begin{gathered}
y=0,093 x+22,65 \\
R^{2}=0,148 \\
y=-0,067 x+23,68 \\
R^{2}=0,092 \\
y=-0,154 x+24,67 \\
R^{2}=0,308 \\
y=-0,015 x+23,34 \\
R^{2}=0,005
\end{gathered}
$$$$
y=-0,131 x+24,33
$$$$
R^{2}=0,302
$$$$
1 \quad \mathrm{y}=-0,144 \mathrm{x}+24,00
$$$$
0 \quad \mathrm{R}^{2}=0,158
$$$$
1 y=-0,105 x+23,54
$$$$
1 \quad \mathrm{R}^{2}=0,199
$$$$
\begin{aligned}
& y=-0,143 x+23,94 \\
& R^{2}=0,278
\end{aligned}
$$

Figure 38. The average weight of 100 seeds of soybeans on intercropping patterns of corns and red chillies.

\section{Conclusions}

1. The using of intercropping system of corns and red chillies has potency to increase soybean production which can be found from the number of pods per plant, the number of piths of pods per plant, and the weight of 100 seeds.

2. The planting on 2 (dua) rows of soybeans with 1 (one) row intercropping of corns and soybeans as the optimal dense population is in order to increase soybean production. 


\section{References}

[1] Adie M.M.,\& Krisnawati. A., 2008. Biologi tanaman kedelai, Balai Penelitian Tanaman Kacangkacangan dan Umbi-umbian. Malang.

[2] Abdurachman, A., Dariah, \& A., Mulyani., 2008. Strataegi dan teknologi pengelolaan lahan kering mendukung pengadaan pangan nasional. Jurnal Litbang Pertanian, vol, 27, no. 2, Bogor.

[3] Badan Litbang Pertanian., 2015.Tumpangsari jagung dengan kedelai dalam sistem tanam legowo. http://new.litbang.pertanian.go.id/info-teknologi/2287/(21 desember 2017).

[4] Fernando J.A., Carneiro M.L., Geraldi I.O., and Appezzato-da- Gloria B. 2002. Anatomical study of somatic embryogenesis in glycine $\max (\mathrm{L}$.) Merill,Brazilian Archives of Biology and Technology, vol. 45, no.3, pp. $277-286$.

[5] Franch J.P., L., Oglesby \& A.C. Zielinski., 1985. Plant regeneration from embryo derived tissue cultures of soy beans. In Vitro Cellular and Developmental Biology,vol. 21,no. 20,pp.653 - 658.

[6] Mathius NT., Wijana G., Guharja E., (2001). Respon tanaman kelapa sawit (Elaeis guineensis Jacq.) terhadap cekaman kekeringan. Menara Perkebunan, vol. 69, no. 2, pp. 29-45.

[7] Jadid MN., (2007). Uji toleransi aksesi kapas (Gossypium hirsutum L.) terhadap cekaman kekeringan dengan menggunakan polietilena glikol (PEG) 6000 Skripsi. Fakultas Sains dan Teknologi Universitas Islam Negeri Malang, Malang.

[8] Marwoto., Suharsono \& Supriyatin., 1999. Hama kedelai dan komponen pengendalian hama terpadu.Monograf Balitkabi,No. 4-1999: 50 (eds) Winarto and N. Saleh.

[9] Marwoto, A., Susilo., R.S., Kusriningrumand Basuki W., 2008. Pengaruh kepadatan populasi hama pengisap polong Riptortus linearis terhadap hasil kedelai. Prosiding Inovasi Teknologi Kacangkacangan dan Umbi-umbian Mendukung Kemandirian Pangan dan Kecukupan Energi, pp.371379.

[10] Suriadikarta, D.A., T. Prihatini, D., Setyorini \&W., Hartatiek., 2002. Teknologi pengelolaan bahan organik tanah. InTeknologi Pengelolaan Lahan Kering Menuju Pertanian Produktif dan Ramah Lingkungan. Pusat Penelitian dan Pengembangan Tanah dan Agroklimat, Bogor, pp. 183-238.

[11] Solichatun., Anggarwulan, E., Mudyantini., W.,2005. Pengaruh ketersediaan air terhadap pertumbuhan dan kandungan bahan aktif saponin tanaman ginseng Jawa (Talinum paniculatum Gaertn.), Biofarmasi,vol. 3, no. 2, pp. 47-51.

[12] Thomas M.J., Robertson S., Fukai., 2003. Respon tanaman kacang-kacangan yang bersifat determinate dan indeterminate pada berbagai kondisi ketersediaan air. Bul. Agron, vol. 31, no. 1, pp. $8-14$. 